\title{
Microsatellite Instability in Glioblastoma: Is It Really Relevant in Tumor Prognosis?
}

\author{
Merih TEPEOGLU ${ }^{1}$, Pelin BORCEK ${ }^{1}$, Ozlem OZEN¹, Nur ALTINORS ${ }^{2}$ \\ ${ }^{1}$ Baskent University, Faculty of Medicine, Department of Pathology, Ankara, Turkey \\ ${ }^{2}$ Baskent University, Faculty of Medicine, Department of Neurosurgery, Ankara, Turkey \\ Corresponding author: Merih TEPEOGLU merihdemirel@yahoo.com.tr
}

\section{ABSTRACT}

AIM: To evaluate the frequency and prognostic significance of microsatellite instability (MSI) in patients with glioblastoma (GBM), an immunohistochemical analysis of mismatch repair (MMR) proteins was performed.

MATERIAL and METHODS: A total of 71 patients with GBM who underwent surgery between 2011 and 2019 , were included in the study. MMR protein expression was examined using immunohistochemistical analysis of tumor tissue samples; the association between the MMR status and clinicopathological findings was evaluated.

RESULTS: Immunohistochemical analysis revealed expressions of MLH1, MSH2, MSH6, and PMS2 proteins in 67 (94.4\%), 65 (91.5\%), 67 (94.4\%), and 64 (90.1\%) patients, respectively. Among the 71 patients, 64 (90.1\%) expressing all MMR proteins were considered microsatellite stable (MSS), and 7 (9.9\%) patients showing loss of at least one of the MMR proteins were considered to show MSI. Tumor recurrence was noted in 25 (39.1\%) patients in the MSS GBM group, and 4 (57.1\%) patients in the MSI GBM group $(p=0.433)$. The overall median survival was $30.65 \pm 5.1$ and $10.71 \pm 5.2$ months in the MSS GBM and MSI GBM groups, respectively $(p=0.059)$.

CONCLUSION: The results of this study showed no significant relationships between MMR protein expression and recurrence rates or overall survival in patients with GBM.

KEYWORDS: Brain neoplasm, Glioblastoma, Microsatellite instability, Mismatch repair

ABBREVIATIONS: MMR: Mismatch repair, MSI: Microsatellite instability, GBM: Glioblastoma, MSS: Microsatellite stable.

\section{INTRODUCTION}

$\mathrm{G}$ lioblastoma (GBM) is the most common and aggressive type of brain tumor in adults $(19,21)$. The standard treatment for GBM is surgical resection followed by local radiotherapy and concomitant chemotherapy with the DNA-methylating agent, temozolomide (30). Despite these treatment modalities, prognosis of GBM is poor with a median overall survival of less than 1 year after diagnosis $(19,21)$. However, the observation that some patients with GBM showed unexpected life spans and prognoses led investigators to search for molecular pathways that might be responsible for these heterogeneities in survival of patients with GBM. Microsatellite instability (MSI) is one of the investigated molecular mechanisms and has been related to prognosis and treatment response in some studies $(9,20,22,23,28,29,31)$.

Microsatellites are short, repeated DNA sequences and are spread throughout human genome. These sequences are extremely prone to DNA replication errors that are readily corrected by DNA mismatch repair (MMR) system (3). Therefore, DNA MMR deficiency is a major cause of genomic instability that results in the accumulation of numerous mutations in microsatellite sequences and leads to MSI. MSI has also been
Merih TEPEOGLU (D) : 0000-0002-9894-8005 Pelin BORCEK (10): 0000-0001-8565-0667
Ozlem OZEN (D) : 0000-0002-9082-1317

Nur ALTINORS : 0000-0003-1346-0041 
demonstrated as an independent prognostic factor in several tumor types such as colonic and endometrioid adenocarcinomas $(3,23,28,29,31)$. The main DNA MMR proteins associated with MSI by inactivation are MutL Protein Homolog 1 (MLH1), MutS Protein Homolog 2 (MSH2), MutS Protein Homolog 6 (MSH6), and Postmeiotic Segregation Increased 2 (PMS2) (3). In this study, we investigated the frequency and the prognostic effect of MSI by evaluating the expression of MMR proteins in GBM.

\section{MATERIAL and METHODS}

The present study includes 71 patients with GBM who underwent surgery between 2011 and 2019 at Baskent University, Department of Neurosurgery. Clinical data were obtained from patient records. All pathological specimens were reevaluated by two pathologists, and diagnosis of GBM was confirmed based on the 2016 World Health Organization (WHO) criteria (19). Isocitrate dehydrogenase (IDH; mouse monoclonal, clone H09) immunohistochemistry (IHC) was performed for samples obtained from 15 (21.1\%) patients. None of these patients displayed IDH positivity. All 15 patients were categorized as GBM IDH wild-type without further need of IDH gene sequencing (age >55 years). The remaining 56 patients in whom neither IDH immunohistochemistry (IHC) nor IDH gene sequencing were performed were classified as GBM not otherwise specified. None of the patients received radiation or chemotherapy before tumor resection. The study protocol was approved by the local Ethics Committees of the Baskent University.

Representative tumor areas with 3- $\mu \mathrm{m}$ thickness were sectioned in paraffin blocks and transferred to poly-L-lysinecovered slides. Immunohistochemical staining procedure was automatically conducted through DAKO Omnis device using EnVisionFLEX IHC kits. Sections were kept in an incubator at $60^{\circ} \mathrm{C}$ for 60 minutes. Clearify (Dako) solution was applied on the sections in the device at $25^{\circ} \mathrm{C}$ for 1 minute for deparaffinization. Sections were then subjected to antigen retrieval to regain antigens. Tissue sections were boiled in EDTA buffer (EnVFLEX HRS, high $\mathrm{pH}$ ) at $97^{\circ} \mathrm{C}$ for 30 minutes for MSH2, MSH6, MLH1, and PMS2 antibodies. After rinsing, the tissue sections were incubated with MSH2 (Monoclonal Mouse, RTU, clone FE11, Dako), MSH6 (Monoclonal Rabbit, RTU, clone EP49, Dako), MLH1 (Monoclonal Mouse, RTU, clone ES05, Dako), and PMS2 (Monoclonal Rabbit, RTU, clone EP51, Dako) antibodies for 30 minutes. Subsequently, tissues processed with primary antibodies were treated with the peroxidase solution of the kit (EnV FLEX PeroxidaseBlocking Reagent, Dako) for 3 minutes to prevent background staining. Tissues were incubated with EnVFLEX/HRP solution for 20 minutes after rinsing. Working solution (EnVFLEX Substrate Working Solution, Dako) containing chromogen and enzyme substrate was applied to the sections for 5 minutes at room temperature, and the sections were rinsed with distilled water. Lastly, counter staining was performed with 5 minutes of hematoxylin staining. The slides were processed with alcohol and xylene and were covered. Tumors with intact immunohistochemical expression of all four MMR proteins were considered microsatellite stable (MSS), whereas tumors with loss of immunohistochemical expression of one or more MMR proteins were considered to show MSI (3). The association between the MMR status and clinical parameters were evaluated.

Descriptive statistics are demonstrated as mean, median, standard deviation, percentages, and range. Categorical variables were compared using Chi-Square test, whereas continuous variables were compared using Kruskal-Wallis and Mann-Whitney $U$ tests. Kaplan-Meier method and logrank analysis were used for actuarial rates of outcome and related factors. All analyses were performed using SPSS software (IBM Corp. Released 2011. Version 20.0.Armonk, NY). Probability values of $<0.05$ were considered as significant.

\section{- RESULTS}

Among the 71 patients, 41 (57.7\%) were male and 30 (42.3\%) were female, with a median age of 58.6 years (range, 3-85 years). The frequencies of tumor location were as follows: $19(26.8 \%)$ in the frontal, $12(16.9 \%)$ in temporal, $22(31 \%)$ in parietal, $8(11.3 \%)$ in occipital, $5(7 \%)$ in frontoparietal, $2(2.8 \%)$ in parietotemporal, $1(1.4 \%)$ in frontotemporal, and $2(2.8 \%)$ in cerebellar regions. In 50 (70.4\%) patients, macroscopic total tumor removal was possible, whereas in 21 (29.6\%) patients, subtotal tumor removal could be performed. None of the patients received preoperative neoadjuvant therapy. Recurrence was detected in 29 (40.8\%) patients, and the mean recurrence period was $11.44 \pm 10.7$ months (range, 2-53 months). In total, 47 (66.2\%) patients died owing to cancer, and the mean survival was $15.45 \pm 13.51$ months from the date of initial diagnosis. The remaining 24 (33.8\%) patients were still alive at the time of study, with a mean survival of $29.47 \pm 26.14$ months. Clinicopathological characteristics of the patients are summarized in Table I.

On performing immunohistochemical evaluation, MLH1 expression was detected in 67 (94.4\%), MSH2 expression in 65 (91.5\%), MSH 6 expression in 67 (94.4\%), and PMS2 expression in 64 (90.1\%) patients. The loss of MLH1, MSH2, MSH6, and PMS2 expression was detected in $4(5.6 \%)$, 6 (8.5\%), 4 (5.6\%), and7 (9.9\%) patients, respectively. The details of immunohistochemical expression of MMR proteins are summarized in Table II. Out of 71 patients with GBM, 7 (9.9\%) patients exhibited loss of expression for at least one MMR protein; 3 showed complete loss of all proteins (Figure 1A-E); 3 showed loss of two proteins (MLH1 and PMS2 were lost in one patient; MSH2 and PMS2 were lost in 2 patients); and 1 patient showed loss of three proteins (MSH2, MSH6, PMS2). The remaining 64 patients (90.1\%) were positive for four MMR proteins (Figure 2A-E). Consequently, 64 patients expressing all MMR proteins were considered MSS, and 7patients showing loss of at least one of the MMR proteins were considered to show MSI. Accordingly, the frequency of $\mathrm{MSI}$ in GBM was found to be $9.9 \%$ in our study group. The most frequently lost MMR protein was PMS2, which was negative in all patients with MSI. Among the 15 patients in whom IDH IHC was performed, 14 showed MSS, whereas only 1 patient showed MSI. 
Table I: Clinicopathological features of Patients with Glioblastoma $(n=71)$

\begin{tabular}{|c|c|c|}
\hline Characteristic & Value & \\
\hline $\begin{array}{l}\text { Age at diagnosis, (years) } \\
\text { Median (range) }\end{array}$ & $58.6(3-85)$ & \\
\hline $\begin{array}{l}\text { Follow-up time (months) } \\
\text { Median (range) }\end{array}$ & $16.1(0-90)$ & \\
\hline Characteristic & $\mathbf{n}$ & $\%$ \\
\hline \multicolumn{3}{|l|}{ Gender } \\
\hline Male & 41 & 57.7 \\
\hline Female & 30 & 42.3 \\
\hline \multicolumn{3}{|l|}{ Tumor location } \\
\hline Frontal & 19 & 26.8 \\
\hline Temporal & 12 & 16.9 \\
\hline Parietal & 22 & 31 \\
\hline Occipital & 8 & 11.3 \\
\hline Frontoparietal & 5 & 7 \\
\hline Parietotemporal & 2 & 2.8 \\
\hline Frontotemporal & 1 & 1.4 \\
\hline Cerebellar & 2 & 2.8 \\
\hline
\end{tabular}

Surgery

\begin{tabular}{ccc}
\hline Total resection & 50 & 70.4 \\
\hline Subtotal resection & 21 & 29.6 \\
\hline
\end{tabular}

\section{Recurrent Disease}

\begin{tabular}{lll}
$(-)$ & 42 & 59.2 \\
\hline$(+)$ & 29 & 40.8 \\
\hline
\end{tabular}

Survival

\begin{tabular}{ccc}
\hline Alive & 24 & 33.8 \\
\hline Death & 47 & 66.2 \\
\hline
\end{tabular}

Microsatellite Instability Status

\begin{tabular}{lrr}
\hline Instable & 7 & 9.9 \\
\hline Stable & 64 & 90.1 \\
\hline
\end{tabular}

Among the 64 patients with MSS, 40 (62.5\%) were male and $24(37.5 \%)$ were female, whereas out of 7 patients with MSI GBMs, 1 (14.3\%) was male and 6 (85.7\%) were female $(p=0.037)$. SI was significantly more common in females than in males in our study group. The mean age of patients with MSI and MSS was $56.29 \pm 15.1$ and $58.86 \pm 13.44$ years, respectively $(p=0.316)$, which was not statistically significant. Among the 7 patients with MSI, tumor was located in the frontal region in 7 patients $(57.1 \%)$, parietal region in 2 patients (28.5\%), and temporal region in 1 patient (14.3\%).
Table II: Immunohistochemical Expression of Mismatch Repair Proteins in Glioblastoma

\begin{tabular}{lrc}
\hline $\begin{array}{l}\text { Mismatch Repair Protein- } \\
\text { Expression }\end{array}$ & $\mathbf{n}$ & $\%$ \\
\hline MLH1 & & \\
\hline$(-)$ & 4 & 5.6 \\
\hline$(+)$ & 67 & 94.4 \\
\hline PMS2 & & \\
\hline$(-)$ & 7 & 9.9 \\
\hline$(+)$ & 64 & 90.1 \\
\hline MSH 2 & & \\
\hline$(-)$ & 6 & 8.5 \\
\hline$(+)$ & 65 & 91.5 \\
\hline MSH 6 & & \\
\hline$(-)$ & 4 & 5.6 \\
\hline$(+)$ & 67 & 94.4 \\
\hline
\end{tabular}

The most frequent locations were parietal $(n=20,31.2 \%)$, frontal $(n=15,23.4 \%)$, and temporal $(n=11,17.1 \%)$ regions in MSS patients. Recurrence was observed in 25 (39.1\%) of 64 patientswith MSS and $4(57.1 \%)$ of 7 patients with MSI $(p=0.433)$. Recurrence rates in patients with MSS and MSI GBM did not differ. The overall survival was $10.71 \pm 5.2$ months in patients with MSI GBM and $30.65 \pm 5.1$ months in those with MSS GBM ( $\mathrm{p}=0.059)$. All patients with MSI died. Of the 64 patients with MSS, 24 (37.5\%) survived and 40 (62.5\%) died $(p=0.087)$. Individual evaluation of each MMR protein expression according to sex, age, presence of recurrence, and overall survival did not reveal any significant correlation as well ( $p>0.05$ for each).

\section{DISCUSSION}

GBM represents the most common and aggressive tumor of the central nervous system, which accounts for $60 \%-70 \%$ of all gliomas, and is classified as a WHO grade IV tumor based onitshistopathological features (19). Histological features of GBM include hypercellularity, nuclear atypia, mitotic activity, microvascular proliferation, and necrosis $(9,19,21,22,30)$. The primary treatment of GBM is surgical resection followed by radiotherapy and adjuvant chemotherapy with temozolomide. The prognosis of GBM is extremely poor with an overall survival time ranging from 12 to 18 months, and less than $5 \%$ of patients survive for more than 5 years after diagnosis $(2,3,20,23,28,29,31,34)$. GBM tends to be highly invasive, shows widespread infiltration of the brain parenchyma, and elicits high vascularity. All these features contributetothe unique aggressiveness of the tumor. Alternatively, well-documented cases of GBM were reported with unexpectedly high survival times and low recurrence rates $(9,20,22,23,28,29,31)$. The investigation of molecular biology of GBM to better predict 

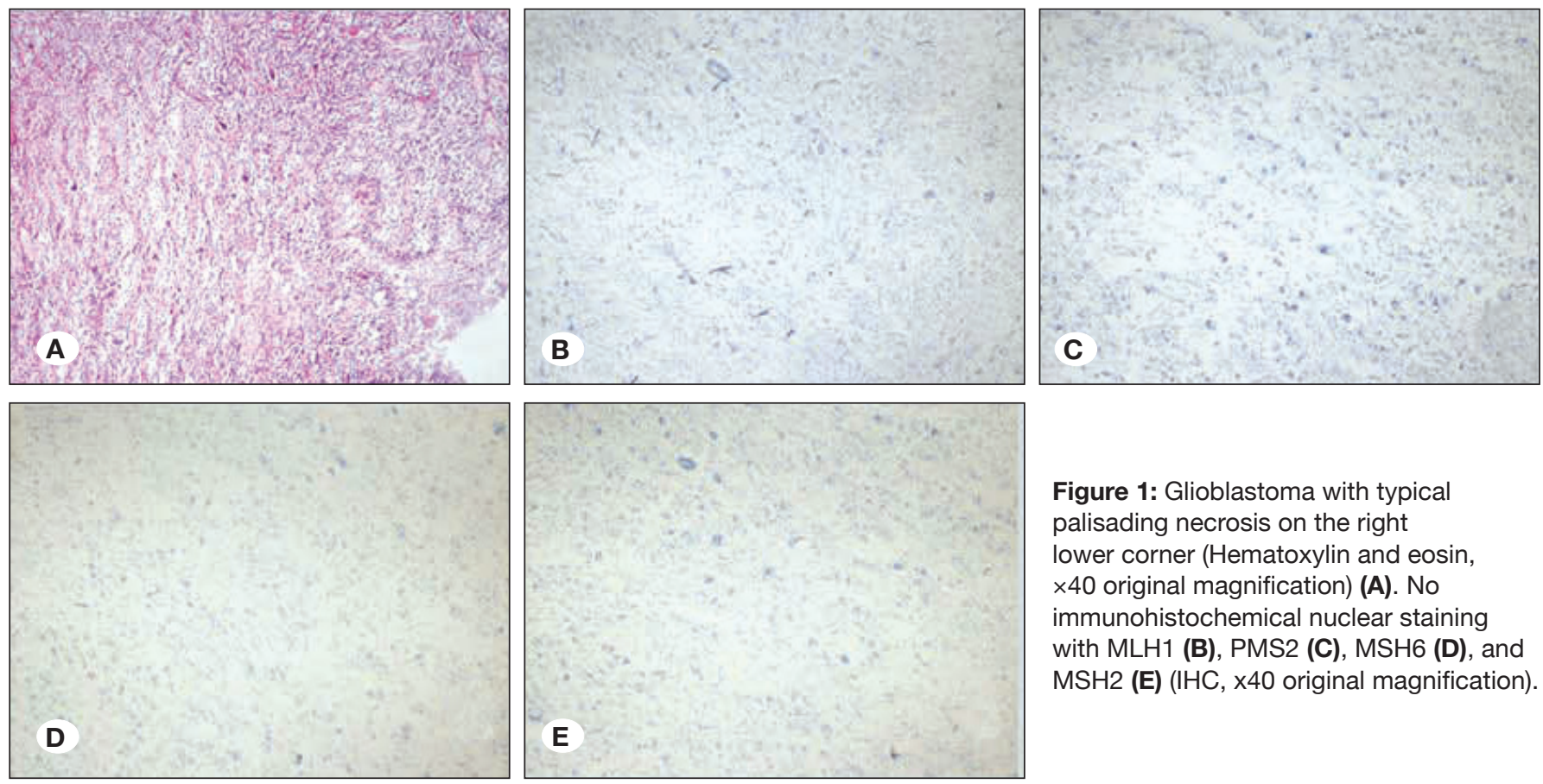

Figure 1: Glioblastoma with typical palisading necrosis on the right lower corner (Hematoxylin and eosin, $\times 40$ original magnification) (A). No immunohistochemical nuclear staining with MLH1 (B), PMS2 (C), MSH6 (D), and $\mathrm{MSH} 2$ (E) (IHC, $x 40$ original magnification).
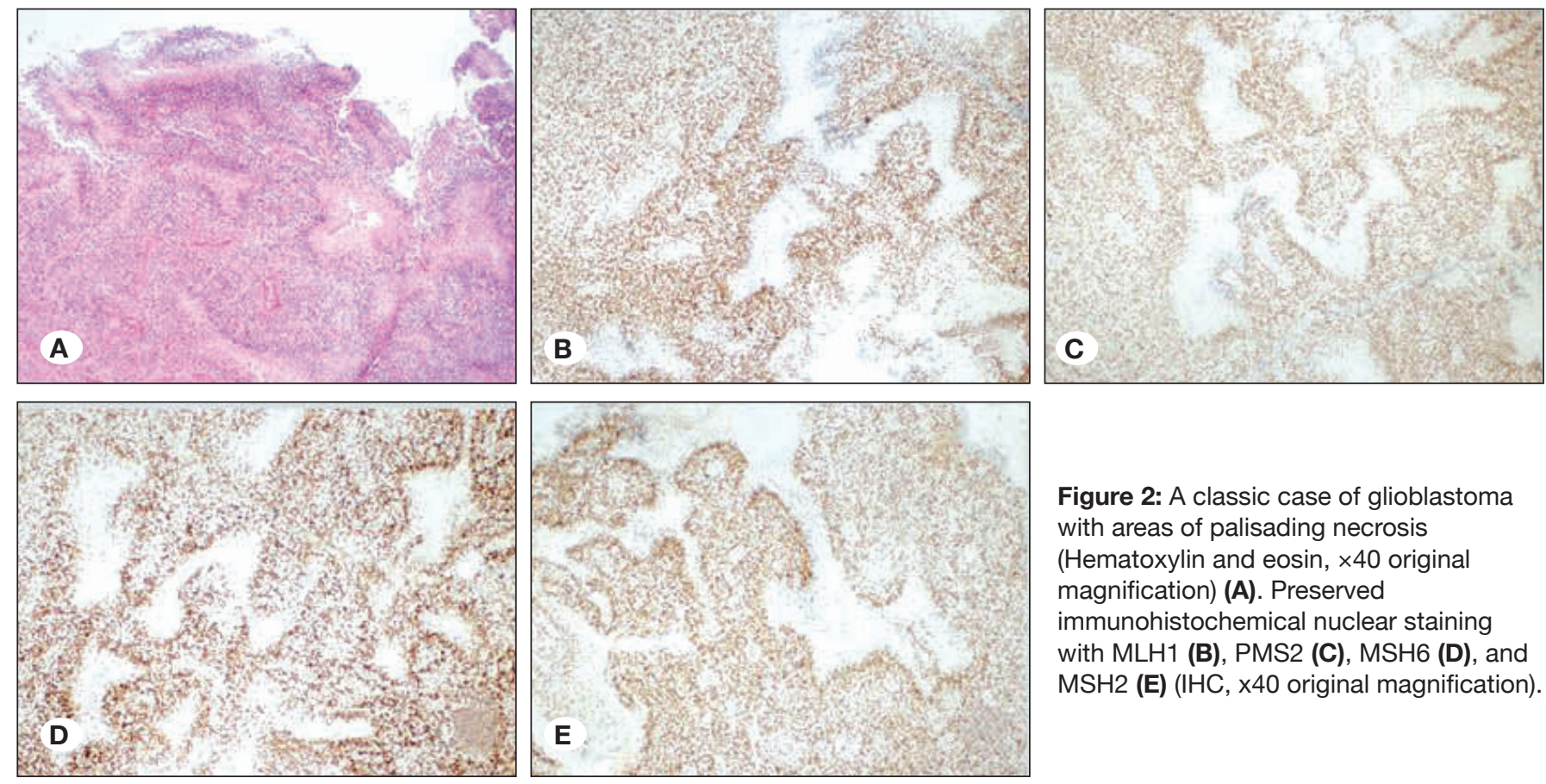

Figure 2: A classic case of glioblastoma with areas of palisading necrosis (Hematoxylin and eosin, $\times 40$ original magnification) (A). Preserved immunohistochemical nuclear staining with MLH1 (B), PMS2 (C), MSH6 (D), and $\mathrm{MSH} 2$ (E) (IHC, x40 original magnification).

survival and determine appropriate treatment modalities is necessary owing to usual poor prognosis and exceptionally long survival times in individual cases.

Genomic instability is the central hallmark of cancer development (12). Therefore, human genome is protected by several mechanisms against genomic stability, such as DNA repair system. DNA MMR pathway repairs inappropriate nucleotide insertions, deletions, and single nucleotide mismatches in repetitive sequences of DNA called microsatellites (3). MSI, which is caused by germline deficiency of the DNA MMR system, is the molecular abnormality observed in tumors associated with Lynch syndrome. Lynch syndrome, also known as hereditary nonpolyposis colorectal cancer, is an autosomal dominant disorder characterized by a high 
risk for colorectal cancer and certain other malignancies in thekidney, ovary, bladder, brain, stomach, pancreas, and lung $(1-3,12,16,24,34)$. MLH1, MSH2, MSH6, and PMS2 are the main proteins involved in this MMR system, and they interact as heterodimers: MSH2 couples with MSH6, and MLH1 couples with PMS2 $(3,10,14,18)$. When MMR is normally functioning, $\mathrm{MSH} 2$ and $\mathrm{MSH} 6$ bind to form the hMutS-a heterodimer, which recognizes and binds to mismatched base pairs and recruits the MLH1-PMS2 hMutL-a heterodimer to repair them $(10,14,18,36)$. If one or more proteins are not expressed, the status is considered MMR deficient; otherwise, the status is considered MMR proficient (3). MLH1 and MSH2 play pivotal roles in the MMR process because they are required to stabilize PMS2 and MSH6; therefore, the loss of MLH1 and MSH2 leads to degradation of their dimers (36).

Methods used in assessing $\mathrm{MSI}$ are polymerase chain reaction $(\mathrm{PCR})$ and $\mathrm{IHC}$. PCR is used to detect instability in microsatellite repeats, whereas $\mathrm{IHC}$ is used to detect the loss of expression of one or more MMR proteins (1). Although PCR is considered gold standard for assessing MSI, IHC has some advantages over PCR, such as shorter turn around time, easier methodology and evaluation, and simultaneous identification of affected MMR genes $(17,24)$. In 1996, the immunohistochemical expression of the MSH2 in fresh-frozen tissues was first reported by Leach et al., shortly after antibodies against MLH1 and MSH2 applicable to paraffin-embedded tissues were identified $(15,32)$. Since then, numerous MMR immunohistochemical studies had been performed. Although the sensitivity of IHC was low when individually studied, it was comparable with PCR when 4MMR genes were studied together; this is because they are dimers of each other, and the mutation that cannot be detected in one becomes detectable when its dimer is studied $(11,25,27)$. In the present study, IHC is the method of choice to detect MMR protein expression and MSI.

Several studies on colorectal cancer have been conducted since the identification of MMR genes; clinicopathological features of these tumors have been clearly identified, and MSI phenotype colorectal cancers have been shown to have a strong association with better outcome $(1,6,10,14,17,18,24,27,36)$. In recent years, MSI has been investigated in many tumors other than colorectal cancer. The most important cause of this is the understanding that MSI status provides both information regarding the prognosis of the patient and predictive value of the effect of immune checkpoint inhibitors. Several studies have demonstrated that MMR deficiency is correlated with an improved overall survival in many tumors (39). Currently, the MSI status of many tumors provides answer to various questions in terms of treatment and prognosis. Because GBM also has poor prognosis, any molecular finding with an impact on treatment becomes important. Therefore, MSI is one of the issues that have been studied in GBM.

The first study regarding $\mathrm{MSI}$ in brain tumors in the literature was published in 1994 by Wooster et al. (37). They evaluated various brain tumors, including gliomas, and genomic instability was reported in $1.8 \%$ of tumors (37). Following this study, Dams et al. investigated MSI in 16 brain tumors, of which 10 were GBM (8). They detected MSI in six patients, of whom $5(31.2 \%)$ had GBM. Subsequently, many studies investigated the frequency of $\mathrm{MSI}$ in GBM. Although results are controversial, the prevalence of $\mathrm{MSI}$ has been reported in approximately $1 \%$ in a considerable number of studies $(4,7,13)$. In the study of Cortes-Ciriano et al. published in 2017 (7), MSI has been studied for 23 cancer types and 7919 patients, whose data were obtained from The Cancer Genome Atlas (35). Of these patients, 316 had GBM with an MSI rate of $1.3 \%(7)$. Similarly, Bonneville et al. reported a study of MSI for 27 different cancer types and 11139 patients in the same year (4). They identified $\mathrm{MSI}$ in $3.8 \%$ of all cancers and $0.25 \%$ of GBM. In 2019, Zhao et al. found $0.25 \% \mathrm{MSI}$ in GBM (39). In a study by Viana-Pereira and colleagues (33), the frequency of $\mathrm{MSI}$ in pediatric high-grade gliomas (WHO grades III and IV) and adult GBM was compared. They evaluated 144 high-grade gliomas, including 71 pediatric and 73 adult patients. MSI was detected in $14(19.7 \%)$ of 71 pediatric high-grade gliomas of which 11 (15.5\%) were GBM. Among the 73 GBMs in adults, MSI was detected in 5 (6.8\%). Based on the immunohistochemical evaluation, MLH1 loss was predominant. They concluded a higher frequency of MSI in pediatric tumors (33). In our study, the frequency of MSI detected by the loss of MMR proteins by IHC is $9.8 \%(7 / 71)$. Although lower rates are generally reported in the literature, there are also high results similar to ours $(4,33)$.

The relationship of MMR deficiency with therapy resistance and recurrence in GBM was highly studied in the literature $(9,20,22,23,28,29,31)$. Most of the studies revealed that MMR deficiency is associated with treatment resistance and recurrence $(9,22)$. In 2007, Cahill et al. described loss of MSH6 in seven out of 17 recurrent GBMs and related MSH6 deficiency to GBM recurrence (5). Felsberg et al. described reduced expression of $\mathrm{MSH} 2, \mathrm{MSH} 6$, and PMS2 proteins in recurrent tumors, but MLH1 expression was not correlated with recurrence (9). In another study published by Shinsato et al., decreases in MLH1 and PMS2 expressions were correlated with GBM recurrence (26). The previously mentioned and many other studies related MSH6 loss with treatment resistance $(5,9,31,38)$. Conversely, some studies in the literature opposed that MMR deficiency is related to treatment resistance and only to a limited extent if there is any (20). None of the patients included in the present study received radiotherapy or chemotherapy prior to surgery; therefore, the relationship between MMR deficiency and therapy resistance or recurrence could not be assessed.

Few studies in the literature show prognostic effect of MSI on GBM. These studies suggest that MSI GBMs show favorable outcome compared with MSS GBMs. In a study by Stark et al., loss of MLH1 and MSH 6 was related to prolonged survival, whereas MSH 2 expression did not correlate with survival (29). However, another study by the same author in 2015 stated that MLH1 and MSH 6 expressions failed to correlate with prognosis (28). Rodriguez-Hernandez et al. analyzed the expression of three MMR proteins, MLH1, MSH6, and MSH2, in 92 astrocytomas, including 57 GBMs (23). None of these tumors were treated with neoadjuvant therapy. A total of 41 (43\%) tumors showed loss of expression of at least one MMR 
protein, and the loss of MSH6 expression was more frequent than the loss of MLH1 or MSH2. Univariate survival analysis revealed that the loss of MSH6 expression was significantly associated with a better median overall survival in high-grade astrocytomas (23). In our study, MSI and MSS GBMs did not significantly differ in terms of overall survival or recurrence. Literature on MSI in GBM is limited. Although majority of these papers related MSI phenotype with favorable prognosis, some failed to demonstrate any relationship between MSI status and survival as noted in our study (28).

\section{CONCLUSION}

Despite the fact that several studies showed favorable outcome of MSI in various tumors, literature on MSI status in GBM displayed conflicting results. One reason might be the relative infrequency of GBM compared with other more extensively studied tumors, such as colonic or endometrioid adenocarcinoma. Another concern on the sensitivity of the method preferred in determining MSI might arise. To demonstrate a stronger correlation of the effect of MSI on survival of patients with GBM, large scale studies with more precise methods should be conducted.

\section{REFERENCES}

1. Aaltonen LA, Salovaara R, Kristo P, Canzian F, Hemminki $A$, Peltomaki $P$, Chadwick RB, Kääriäinen $H$, Eskelinen $M$, Järvinen $H$, Mecklin JP, de la Chapelle A: Incidence of hereditary nonpolyposis colorectal cancer and the feasibility of molecular screening for the disease. $\mathrm{N}$ Engl J Med 338: 1481-1487, 1998

2. Aldape K, Zadeh G, Mansouri S, Reifenberger G, Deimling A: Glioblastoma: Pathology, molecular mechanisms and markers. Acta Neuropathol 129:829-848, 2015

3. Baretti M, Le DT: DNA mismatch repair in cancer. Pharmacology and Therapeutics 189:45-62, 2018

4. Bonneville R, Krook MA, Kautto EA, Miya J, Wing MR, Chen $\mathrm{HZ}$ : Landscape of microsatellite instability across 39 cancer types. JCO Precision Oncology 1:1-15, 2017

5. Cahill DP, Levine KK, Betensky RA, Codd PJ, Romany CA, Reavie LB, Batchelor TT, Futreal PA, Stratton MR, Curry WT, lafrate AJ, Louis DN: Loss of the mismatch repair protein MSH6 in human glioblastomas is associated with tumor progression during temozolomide treatment. Clin Cancer Res 13:2038-2045, 2017

6. Chen W, Swanson BJ, Frankel WL: Molecular genetics of microsatellite-unstable colorectal cancer for pathologists. Diagn Pathol 12:1-12, 2017

7. Cortes-Ciriano I, Lee S, Park WY, Kim TM, Park PJ: A molecular portrait of microsatellite instability across multiple cancers. Nat Commun 8:1-12, 2017

8. Dams E, van de Kelft EJZ, Martin JJ, Verlooy J, Willems PJ: Instability of microsatellites in human gliomas. Cancer Research 55:1547-1549,1995
9. Felsberg J, Thon N, Eigenbrod S, Hentschel B, Sabel MC, Westphal M, Schackert G, Kreth FW, Pietsch T, Löffler M, Weller M, Reifenberger G, Tonn JC: Promoter methylation and expression of MGMT and the DNA mismatch repair genes MLH1, MSH2, MSH6 and PMS2 in paired primary and recurrent glioblastomas. Int J Cancer 129:659-670, 2011

10. Fishel R, Lescoe MK, Rao MR, Copeland NG, Jenkins NA, Garber J, Kane M, Kolodner R: The human mutator gene homolog $\mathrm{MSH} 2$ and its association with hereditary nonpolyposis colon cancer. Cell 75:1027-1038,1993

11. Hampel H, Frankel WL, Martin E, Arnold M, Khanduja K, Kuebler P, Nakagawa H, Sotamaa K, Prior TW, Westman J, Panescu J, Fix D, Lockman J, Comeros I, de La Chapelle A: Screening for the Lynch syndrome (hereditary nonpolyposis colorectal cancer). N Eng J Med 352:1851-1860, 2005

12. Hanahan D, Weinberg RA: Hallmarks of cancer: The next generation. Cell 144:646-674, 2011

13. Hause RJ, Pritchard CC, Shendure J, Salipante SJ: Classification and characterization of microsatellite instability across 18 cancer types. Nature Medicine 22:1342-1350, 2016

14. Kolodner RD, Tytell JD, Schmeits JL, Kane MF, Gupta RD, Weger J, Wahlberg S, Fox EA, Peel D, Ziogas A, Garber JE, Syngal S, Anton-Culver H, Li FP: Germ-line Msh6 mutations in colorectal cancer families. Cancer Res 59:5068-5074, 1999

15. Leach FS, Polyak K, Burrel M, Johnson KA, Hill D, Dunlop MG, Wyllie AH, Peltomaki P, de la Chapelle A, Hamilton SR, Kinzler KW, Vogelstein B: Expression of the human mismatch repair gene hMSH2 in normal and neoplastic tissues. Cancer Res 56:235-240, 1996

16. Lin KM, Shashidharan M, Thorson AG, Ternent CA, Blatchford GJ, Christensen MA, Watson P, Lemon SJ, Franklin B, Karr $B$, Lynch J, Lynch HT: Cumulative incidence of colorectal and extracolonic cancers in $\mathrm{MLH} 1$ and $\mathrm{MSH} 2$ mutation carriers of hereditary nonpolyposis colorectal cancer. J Gastrointest Surg 2:67-71, 1998

17. Lindor NM, Burgart LJ, Leontovich O, Goldberg RM, Cunningham JM, Sargent DJ, Walsh-Vockley C, Petersen GM, Walsh MD, Leggett BA, Young JP, Barker MA, Jass JR, Hopper J, Gallinger S, Bapat B, Redston M, Thibodeau SN: Immunohistochemistry versus microsatellite instability in phenotyping colorectal tumors. J Clin Oncol 20:1043-1048, 2002

18. Liu B, Parsons R, Papadopoulos N, Nicolaides NC, Lynch HT, Watson P, Jass JR, Dunlop M, Wyllie A, Peltomäki P, de la Chapelle A, Hamilton SR, Vogelstein B, Kinzler KW: Analysis of mismatch repair genes in hereditary non-polyposis colorectal cancer patients. Nat Med 2:169-174, 1996

19. Louis DN, Ohgaki H, Wiestler OD, Cavenee WK, Ellison DW: Diffuse astrocytic and oligodendroglial tumours. In: WHO Classification of Tumors of the Central Nervous System. Revised $4^{\text {th }}$ ed. Lyon, 2016:16-56

20. Maxwell JA, Johnson SP, McLendon RE, Lister DW, Horne KS, Rasheed A, Quinn JA, Ali-Osman F, Friedman AH, Modrich PL, Bigner DD, Friedman HS: Mismatch repair deficiency does not mediate clinical resistance to temozolomide in malignant glioma. Clin Cancer Res 14:4859-4868, 2008 
Tepeoglu M. et al: Microsatellite Instability in Glioblastoma

21. Ohgaki $H$, Kleihues $P$ : Population-based studies on incidence, survival rates, and genetic alterations in astrocytic and oligodendroglial gliomas. J Neuropathol Exp Neurol 64:479-489, 2005

22. Rellecke P, Kuchelmeister K, Schachenmayr W, Schlegel J: Mismatch repair protein $\mathrm{hMSH} 2$ in primary drug resistance in in vitro human malignant gliomas. J Neurosurg 101:653658, 2004

23. Rodriguez-Hernandez I, Garcia JL, Santos-Briz A, Hernandez-Lain A, Gonzalez-Valero JM, Gomez-Moreta JA, Toldos-Gonzalez O, Cruz JJ, Martin-Vallejo J, GonzalezSarmiento R: Integrated analysis of mismatch repair system in malignant astrocytoma. PLoS One 8:1-10, 2013

24. Shia J: Evolving approach and clinical significance of detecting DNA mismatch repair deficiency in colorectal carcinoma. Semin Diagn Pathol 32:352-361, 2015

25. Shia J, Holck S, DePetris G, Greenson JK, Klimstra DS: Lynch syndrome-associated neoplasms: A discussion on histopathology and immunohistochemistry. Fam Cancer 12: 241-260, 2013

26. Shinsato $\mathrm{Y}$, Furukawa T, Yunoue S, Yonezawa H, Minami K, Nishizawa Y, Ikeda R, Kawahara K, Yamamoto M, Hirano H, Tokimura H, Arita K: Reduction of MLH1 and PMS2 confers temozolomide resistance and is associated with recurrence of glioblastoma. Oncotarget 4:2261-2270, 2013

27. Southey MC, Jenkins MA, Mead L, Whitty J, Trivett $M$, Tesoriero AA, Smith LD, Jennings K, Grubb G, Royce SG, Walsh MD, Barker MA, Young JP, Jass JR, St John DJ, Macrae FA, Giles GG, Hopper JL: Use of molecular tumor characteristics to prioritize mismatch repair gene testing in early-onset colorectal cancer. J Clin Oncol 23:6524-6532, 2005

28. Stark AM, Doukas A, Hugo HH, Hedderich J, Hattermann $\mathrm{K}$, Mehdorn HM, Held-Feindt: Expression of DNA mismatch repair proteins $\mathrm{MLH} 1, \mathrm{MSH} 2$ and $\mathrm{MSH} 6$ in recurrent glioblastoma. Neurol Res 37:95-105, 2015

29. Stark AM, Doukas A, Hugo HH, Mehdorn HM: The expression of mismatch repair proteins $\mathrm{MLH} 1, \mathrm{MSH} 2$ and $\mathrm{MSH} 6$ correlates with the Ki67 proliferation index and survival in patients with recurrent glioblastoma. Neurol Res 32:816-820, 2010

30. Stupp R, Mason WP, van den Bent MJ, Weller M, Fisher B, Taphoorn MJ, Belanger K, Brandes AA, Marosi C, Bogdahn U, Curschmann J, Janzer RC, Ludwin SK, Gorlia T, Allgeier A, Lacombe D, Cairncross JG, Eisenhauer E, Mirimanoff RO: Radiotherapy plus concomitant and adjuvant temozolomide for glioblastoma. N Eng J Med 352:987-996,2005
31. Sun $Q$, Pei C, Li Q, Dong T, Dong Y, Zhou P, Gong P, Gong Y, Zhen Z, Gao Y, Xiao Y, Su J, Ren H: Up-regulation of MSH6 is associated with temozolomide resistance in human glioblastoma. Biochem Biophys Res Commun 496:10401046, 2018

32. Thibodeau SN, French AJ, Roche PC, Cunningham JM, Tester DJ, Lindor NM, Moslein G, Baker SM, Liskay RM, Burgart LJ, Honchel R, Halling KC: Altered expression of $\mathrm{hMSH} 2$ and $\mathrm{hMLH} 1$ in tumors with microsatellite instability and genetic alterations in mismatch repair genes. Cancer Res 56:4836-4840, 1996

33. Viana-Pereira M, Lee A, Popov S, Bax DA, Al-Sarraj S, Bridges LR, Stavale JN, Hargrave D, Jones C, Reis RM: Microsatellite instability in pediatric high grade glioma is associated with genomic profile and differential target gene inactivation. PLoS One 6:1-10, 2011

34. Walker MD, Alexander E, Hunt WE, MacCarty CS, Mahaley MS, Mealey J, Norrell HA, Owens G, Ransohoff J, Wilson CB, Gehan EA, Strike TA: Evaluation of BCNU and/or radiotherapy in the treatment of anaplastic gliomas. A cooperative clinical trial. J Neorosurg 49:333-343, 1978

35. Weinstein JN, Collisson EA, Mills GB, Shaw KR, Ozenberger BA, Ellrott K, Shmulevich I, Sander C, Stuart JM: The cancer genome atlas pan-cancer analysis project. Nat Genet 45:1113-1120, 2013

36. Wheeler JM, Bodmer WF, Mortensen NJ: DNA mismatch repair genes and colorectal cancer. Gut 47:148-153, 2000

37. Wooster R, Cleton-Jansen AM, Collins N, Mangion J, Cornelis RS, Cooper CS, Gusterson BA, Ponder BAJ, von Deimling A, Wiestler OD, Cornelisse CJ, Devilee P, Stratton MR: Instability of short tandem repeats (microsatellites) in human cancers. Nat Genet 6:152-156, 1994

38. Yip S, Miao J, Cahill DP, lafrate AJ, Aldape K, Nutt CL, Louis DN: MSH6 mutations arise in glioblastomas during temozolomide therapy and mediate temozolomide resistance. Clin Cancer Res 15:4622-4629, 2009

39. Zhao P, Li L, Jiang X, Li Q: Mismatch repair deficiency/ microsatellite instability-high as a predictor for anti-PD-1/ PD-L1 immunotherapy efficacy. Journal of Hematology and Oncology 12:1-14, 2019 